\title{
UJI DRUG LOADING IBUPROFEN PADA MATERIAL UiO-66 (Zr-METAL ORGANIC FRAMEWORK)
}

\author{
Tri Ana Mulyati*, Fery Eko Pujiono \\ S1 Kimia, Institut Ilmu Kesehatan Bhakti Wiyata \\ "email: nanapujiono@gmail.com
}

Received 12 November 2019

Accepted 31 December 2019

\begin{abstract}
Abstrak
Telah dilakukan penelitian uji drug loading ibuprofen pada material UiO-66 (Zr-Metal Organic Framework). Pada penelitian ini, dilakukan variasi lama perendaman 12, 24, 36, 48, 60 dan 72 jam, sehingga didapatkan nilai drug loading yang optimal. Nilai drug loading ibuprofen diukur menggunakan spektrofotometer UV-VIS. Adapun penyimpanan ibuprofen dalam UiO-66 dikonfirmasi dengan XRD, FTIR, dan SEM-EDX. Hasil analisa gugus fungsi sampel dengan Fourier-Transform Infra Red (FTIR) dari Zr-MOF menunjukkan bahwa puncak khas dari UiO-66 juga muncul pada 663,748 dan $547 \mathrm{~cm}^{-1}$ yang menunjukkan adanya interaksi Zirkonium $(\mathrm{Zr})$ dengan ligan $\mathrm{H}_{2} \mathrm{BDC}$, setelah UiO-66 digunakan untuk loading Ibuprofen tidak mengubah posisi dari puncak-puncak UiO-66. Namun, terjadi penurunan intensitas dan hilangnya puncak disekitar $1300 \mathrm{~cm}^{-1}$ yang dikarenakan interaksi antara UiO-66 dengan ibuprofen. Pola difraktogram UiO-66 sebelum dan sesudah loading ibuprofen yang menunjukkan bahwa UiO-66 yang terbentuk memiliki puncak karakteristik UiO-66 pada 7,3 ${ }^{\circ}$. Mikrograf UiO-66 sebelum dan setelah loading ibuprofen memiliki morfologi kubus. Namun, setelah loading ibuprofen terdapat bagian seperti karang putih, ukuran yang terlihat lebih besar, serta pengurangan ruang kosong permukaan material. Uji Drug Loading Ibuprofen pada UiO-66 menunjukkan loading optimum ibuprofen dalam ZrMOF mencapai $82,79 \%$ pada waktu pengadukan 72 jam.
\end{abstract}

Katakunci: Drug loading, Ibuprofen, UiO-66, Zr-Metal Organic Framework

\begin{abstract}
A study about drug loading ibuprofen on UiO-66 (Zr-Metal Organic Framework) has been done. In this study, variations in soaking time of 12, 24, 36, 48, 60 and 72 hours were carried out to obtain optimal drug loading values. The value of drug loading ibuprofen was measured using a UV-VIS spectrophotometer. The storage of ibuprofen in UiO-66 was confirmed by XRD, FTIR, and SEM-EDX. The results of the analysis of sample functional groups with Fourier-Transform Infra-Red (FTIR) from Zr-MOF showed that the typical peak of UiO-66 also appeared at 663, 748 and $547 \mathrm{~cm}-1$ which indicated the interaction of Zirconium $(\mathrm{Zr})$ with $\mathrm{H}_{2} \mathrm{BDC}$ ligands, after UiO-66 used for loading Ibuprofen does not change the position of the tops of UiO-66. However, there was a decrease in intensity and loss of peaks around $1300 \mathrm{~cm}-1$ due to interactions between UiO-66 and ibuprofen. The diffractogram of UiO-66 before and after loading of ibuprofen which shows that the formed UiO-66 has a characteristic peak of UiO-66 at 7.3 . UiO-66 micrographs before and after loading ibuprofen have cube morphology. However, after loading ibuprofen, there are parts such as white coral, the size of which looks larger, as well as the reduction in the free space of the material surface. The Ibuprofen Drug Loading test on UiO-66 showed the optimum loading of ibuprofen in Zr-MOF reaching $82.79 \%$ at 72 hours of stirring.
\end{abstract}

Keywords: Drug loading, Ibuprofen, UiO-66, Zr-Metal Organic Framework 


\section{Pendahuluan}

Ibuprofen merupakan derivate asam propionat, bersifat analgesik dan antipiretik, serta sering digunakan sebagai pereda nyeri ringan, nyeri sedang dan peradangan (Nurahmanto, et al., 2017). Ibuprofen memiliki waktu paruh eliminasi yang cepat (sekitar 2 jam) sehingga ibuprofen harus sering dikonsumsi (Sa'diah, 2017). Disisi lain, bila ibuprofen dikonsumsi dalam jumlah yang berlebih dapat menyebabkan iritasi lambung. Hal ini menunjukkan bahwa dibutuhkan material yang mampu menyimpan ibuprofen dalam jumlah yang besar.

Beberapa material yang dikembangkan sebagai drug storage (penyimpan obat) antara lain polimer, zeolite, silica mesopori, dan MOF (Metal Organic Framework). Bila dibandingkan dengan material lainnya, MOF memiliki kelebihan mudah disintesis serta dapat dimodifikasi ion logam dan ligan organik yang digunakan, sehingga menghasilkan MOF dengan porositas, luas permukaan dan ukuran pori yang bervariasi sesuai dengan aplikasinya (Mulyati, et al., 2015). MOF dapat diaplikasikan sebagai drug storage (penyimpan obat) maupun drug delivery (penghantar obat) karena MOF bersifat biodegradable, memiliki kestabilan yang tinggi, serta mampu mengikat molekul obat dengan baik (Tai, et al., 2016; Della, et al., 2011). Salah satu jenis MOF yang dapat digunakan sebagai material penyimpan obat (drug storage) adalah ZrMetal Organic Framework (UiO-66).

UiO-66 tersusun dari logam $\left(\mathrm{Zr}_{6} \mathrm{O}_{4}(\mathrm{OH})_{4}\right)$ dan ligan organik $\left(\mathrm{H}_{2} \mathrm{BDC}\right)$ yang tidak beracun serta biocompatible (Tai, et al., 2016). Disamping itu UiO-66 memiliki luas permukaan besar, stabilitas tinggi, berukuran nano dan porositas yang tinggi (Cavka, et al., 2008; Abid, et al., 2012) sehingga cocok digunakan sebagai drug storage (penyimpan obat) maupun drug delivery (penghantar obat). Material

Material yang digunakan pada penelitian ini antara lain Zirconium Online ISSN: 2528-0422
Hal ini sesuai dengan penelitian Rojas, et al., (2018) yang menunjukkan bahwa beberapa jenis MOF telah berhasil digunakan sebagai material penyimpan ibuprofen, yaitu MOF jenis MIL (Materials of Institut Lavoisier) yaitu MIL-100 dan MIL-127 serta MOF jenis $\mathrm{UiO}$ (University of Oslo) yaitu UiO-66. Disisi lain, hasil penelitian Rojas, et al., (2018) menunjukkan bahwa selama 24 jam, drug loading ibuprofen pada UiO-66 mencapai 35,5 wt\% sedangkan MIL-100 hanya mencapai 30,6 wt\% dan MIL 127 hanya mencapai 13,6 wt\%. Hal ini menunjukkan bahwa UiO-66 (Zr-Metal Organic Framework) merupakan jenis MOF yang efektif digunakan sebagai material penyimpan ibuprofen.

Hasil penelitian lainnya menunjukkan bahwa ada perbedaan nilai drug loading optimal ibuprofen pada berbagai waktu perendaman. Hasil penelitian $\mathrm{Li}$, et al., (2015) menunjukkan bahwa $\mathrm{Fe}_{3} \mathrm{O}_{4} @ \mathrm{MOFs} / \mathrm{GO}$ mampu menyimpan ibuprofen sampai $100 \%$ setelah 120 jam perendaman. Disamping itu, Sun, et al., (2017) melaporkan bahwa MOF jenis HKUST mampu menyimpan ibuprofen sampai $60 \%$ setelah 24 jam perendaman. Hal ini menunjukkan bahwa waktu perendaman berpengaruh terhadap nilai drug loading.

Berdasarkan latar belakang di atas, dilakukan sintesis UiO-66 (Zr-Metal Organic Framework) yang selanjutnya digunakan sebagai penyimpan ibuprofen. Pada penelitian ini, dilakukan variasi lama perendaman 12, 24, 36, 48, 60 dan $72 \mathrm{jam}$, sehingga didapatkan nilai drug loading yang optimal. Nilai drug loading ibuprofen diukur menggunakan spektrofotometer UV-VIS. Adapun penyimpanan ibuprofen dalam UiO-66 dikonfirmasi dengan XRD, FTIR, dan SEM-EDX.

\section{Metode Penelitian}

tetraclorida $\left(\mathrm{ZrCl}_{4}\right)$ (pa Merck), Benzene1,4-dicarboxylic acid $\left(\mathrm{H}_{2} \mathrm{BDC}\right)$ (pa Merck), Dimethylformamide (DMF) (pa 
Merck), Kloroform (pa Merck), Metanol (pa Merck), ibuprofen (Asam ( \pm )-2-(4Isobutilfenil)propanoat, Merck, 98\%).

\section{Sintesis UiO-66 (Zr-Metal Organic Framework)}

Pembuatan UiO-66 dilakukan dengan memodifikasi metode Abid, et al., (2012) dan Rahmawati et al., (2014) yaitu dengan cara melarutkan 0,53 gram Zirconium tetraclorida $\left(\mathrm{ZrCl}_{4}\right)$ dan 0,34 gram Benzene-1,4-dicarboxylic acid $\left(\mathrm{H}_{2} \mathrm{BDC}\right)$ dalam $30 \mathrm{~mL}$ Dimethylformamide (DMF). Larutan ini kemudian distirrer selama 30 menit lalu dipanaskan dalam oven pada suhu $120^{\circ} \mathrm{C}$ selama 24 jam. Hasilnya didinginkan pada suhu ruang sampai semalam. Larutan kemudian disekantasi, padatannya dicuci dengan $30 \mathrm{~mL}$ DMF lalu dibiarkan selama semalam. Padatan dicuci kembali dengan $30 \mathrm{~mL}$ kloroform sebanyak dua kali. Hasil padatan yang telah dicuci, kemudian dikeringkan dalam $50^{\circ} \mathrm{C}$ selama $24 \mathrm{jam}$.

\section{Karakterisasi}

Kristalinitas, kemurnian fasa, dan identitas sampel ditentukan dengan difraktometer sinar-X (XRD, D8 AdvanceBruker aXS) menggunakan radiasi $\mathrm{Cu} \mathrm{Ka}$ $(\mathrm{k}=1,5406 \AA)$, dengan tegangan dan arus percepatan masing-masing $40 \mathrm{kV}$ dan 40 $\mathrm{mA}$. Morfologi sampel diperiksa dengan Scanning Electron Microscope (SEM, Zeiss EVO MA 10) dan kandungan unsur diukur dengan Energy Dispersive X-Ray (EDX). Spektra IR sampel ditentukan Fourier Transform Infrared (FT-IR, Shimadzu FTIR036) pada Wavenumber $400-4500 \mathrm{~cm}^{-1}$.

\section{Uji Drug Loading Ibuprofen}

Pengujian drug loading ibuprofen dilakukan dengan memodifikasi metode Sun, et al., (2017) dan Tai, et al., (2016) yaitu 0,2 gram UiO-66 didispersikan dalam $10 \mathrm{~mL}$ etanol lalu ditambahkan 10 $\mathrm{mL}$ larutan ibuprofen $1000 \mathrm{ppm}$. Campuran di stirrer pada suhu ruang selama 12, 24, 48, dan 72 jam. Hasilnya disentrifus dan dicuci dengan air selama 3 kali, lalu diukur kadar ibuprofen dalam UiO-66 dengan UV-VIS. Hasil uji drug loading ibuprofen pada UiO-66 diukur menggunakan persamaan (1).

$$
q_{e}=\left(C_{o}-C_{e}\right) \frac{w}{m}
$$

Dimana Co dan $\mathrm{Ce}$ adalah konsentrasi awal dan konsentrasi pada waktu tertentu, w menunjukkan volume cair (L) sedangkan $\mathrm{m}$ menunjukkan berat ibuprofen $(\mathrm{g})$.

\section{Hasil dan Pembahasan}

Pada penelitian ini, UiO-66 (UiO-66 ) disintesis dengan mereaksikan larutan $\mathrm{ZrCl}_{4}$ dan larutan $\mathrm{H}_{2} \mathrm{BDC}$ (Benzene-1,4dicarboxylic acid) dalam pelarut $\mathrm{DMF}$ (Dimethylformamide). Metode yang digunakan pada sintesis UiO-66 ini adalah solvothermal. Terbentuknya padatan UiO66 ditunjukkan melalui terbentunya padatan putih sesuai hasil penelitian Rahmawati, et al., (2014). UiO-66 yang telah dihasilkan selanjutnya digunakan sebagai material penyimpan ibuprofen. Uji drug loading ibuprofen pada berbagai waktu perendaman ini diukur menggunakan spektroskopi UV-VIS. Terbentuknya UiO-66 serta adsorpsi ibuprofen pada UiO-66 selanjutnya dikonfirmasi melalui spektra FTIR, XRD, dan SEM-EDX. 


\section{Analisa FTIR}

Hasil analisa gugus fungsi sampel dengan Fourier-Transform Infra Red (FTIR) dari sampel ditunjukkan pada Gambar 1. Pada Spektra FTIR menunjukkan bahwa terdapat puncak pada 1656, 1579, dan $1398 \mathrm{~cm}^{-1}$ yang menunjukkan adanya gugus karboksilat (Kandiah, et al., 2010; Jin dan Yang, 2017). Puncak pada $1656 \mathrm{~cm}^{-1}$ menunjukkan vibrasi regang $\mathrm{C}=\mathrm{O}$ dari gugus karboksilat, $1579 \mathrm{~cm}^{-1}$ menunjukkan adanya C-C pada gugus aromatis, dan $1398 \mathrm{~cm}^{-1}$ menunjukkan vibrasi regang dari O-C-O dari karboksilat.

Puncak khas dari UiO-66 juga muncul pada 663, 748 dan $547 \mathrm{~cm}^{-1}$ yang menunjukkan adanya interaksi Zirkonium
( $\mathrm{Zr}$ ) dengan ligan $\mathrm{H}_{2} \mathrm{BDC}$ (Chavan, et al., 2012; DeCoste, et al., 2013). Pada $663 \mathrm{~cm}^{-}$ 1 menunjukkan adanya vibrasi bengkok dari $\mathrm{O}-\mathrm{H}, 748 \mathrm{~cm}^{-1}$ menunjukkan adanya $\mathrm{Zr}-\mathrm{O}$, dan $547 \mathrm{~cm}^{-1}$ menunjukkan vibrasi regang asimetris $\mathrm{Zr}$-(OC). Disisi lain, setelah UiO-66 digunakan untuk adsorpsi Ibuprofen tidak mengubah posisi dari puncak-puncak UiO-66. Hal ini menunjukkan bahwa adsorpsi Ibuprofen tidak merusak struktur dari UiO-66 (Jin dan Yang, 2017). Namun, Perbedaan terdapat pada penurunan intensitas dan hilangnya puncak disekitar $1300 \mathrm{~cm}^{-1}$ yang dikarenakan interaksi antara UiO-66 dengan ibuprofen (Rojas, et al., 2018; Sun, et al., 2019).

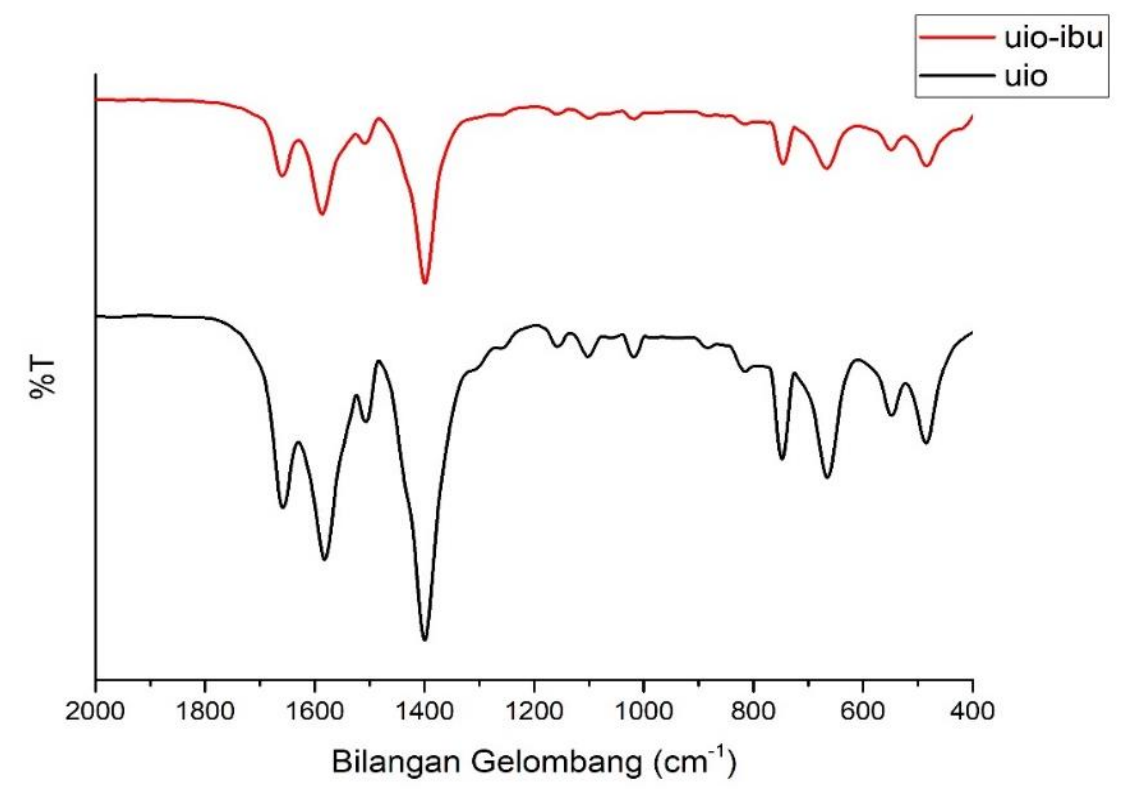

Gambar 1. Spektra FTIR : UiO-66 (Hitam); UiO-66 Loaded Ibuprofen (Merah)

\section{Analisa XRD}

Pola difraktogram UiO-66 sebelum dan sesudah loading ibuprofen ditunjukkan pada Gambar 2 yang menunjukkan bahwa UiO-66 yang terbentuk memiliki puncak karakteristik UiO-66 pada 7,3 ${ }^{\circ}$. Disamping itu, terdapat pula puncak dengan intensitas rendah pada $8,4^{\circ} ; 25,6^{\circ}$; dan $30,6^{\circ}$ sesuai dengan hasil penelitian Rahmawati, et al., (2014) dan Ragon, et al., (2014). Hal ini menunjukkan bahwa UiO-66 telah berhasil disintesis. Disisi lain, intensitas puncak karakteristik UiO-66 menurun secara signifikan setelah loading ibuprofen. Hal ini sesuai dengan penelitian $\mathrm{Li}$, et al., (2017) yang melaporkan bahwa intensitas CD-MOF akan menurun secara signifikan setelah loading ibuprofen. Disamping itu, pola difraktogramnya UiO-66 sebelum dan sesudah loading ibuprofen relatif sama. Hal ini menunjukkan bahwa UiO-66 
memiliki struktur yang stabil (Haydar, et al., 2017).

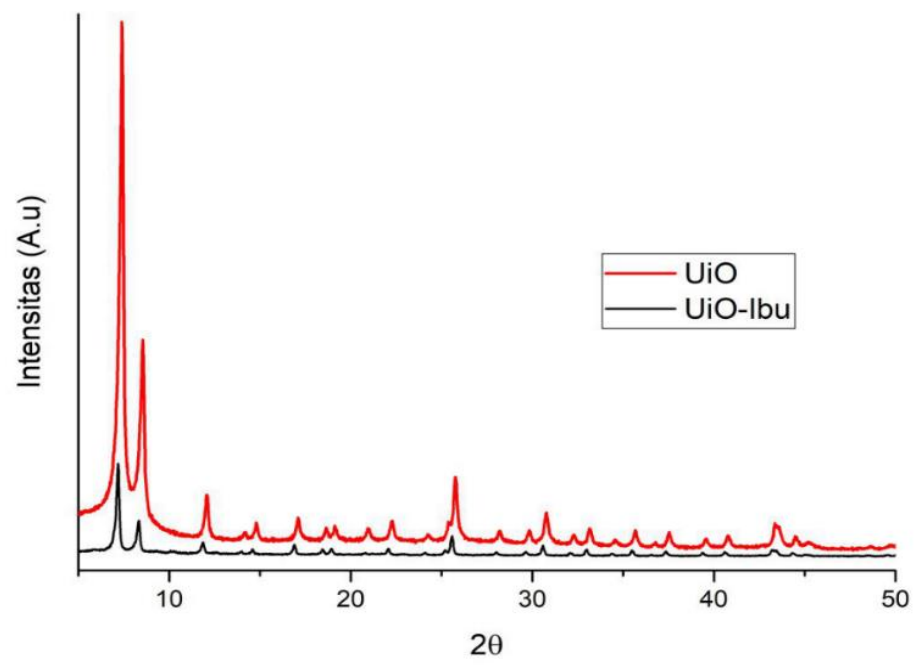

Gambar 2. Difraktogram XRD: UiO-66 (Merah); UiO-66 Loaded Ibuprofen (Hitam)

\section{Analisa SEM-EDX}

Morfologi permukaan UiO-66 sebelum dan sesudah loading ibuprofen ditunjukkan pada Gambar 3. Mikrograf pada Gambar 3 menunjukkan bahwa UiO66 memiliki morfologi kubus sesuai hasil penelitian Rahmawati, et al., (2014). Hasil ini sesuai dengan spektra FTIR dan pola difraktogram yang menunjukkan bahwa UiO-66 telah berhasil disintesis. Mikrograf pada Gambar 3 menunjukkan bahwa setelah loading ibuprofen, terdapat bagian seperti karang putih, ukuran yang terlihat lebih besar, serta pengurangan ruang kosong permukaan material. Hasil ini mungkin disebabkan adanya tumpang tindih ibuprofen pada UiO-66 sesuai dengan hasil penelitian Ulfa, et al., (2019).

Di samping itu, Gambar 3 juga menunjukkan bahwa morfologi permukaan UiO-66 sesudah loading ibuprofen masih tetap kubus. Hasil ini menunjukkan bahwa ibuprofen tidak hanya masuk kedalam pori UiO-66, namun juga melapisi permukaan UiO-66. Loading ibuprofen dalam UiO-66 juga ditunjukkan dari hasil analisa EDX.
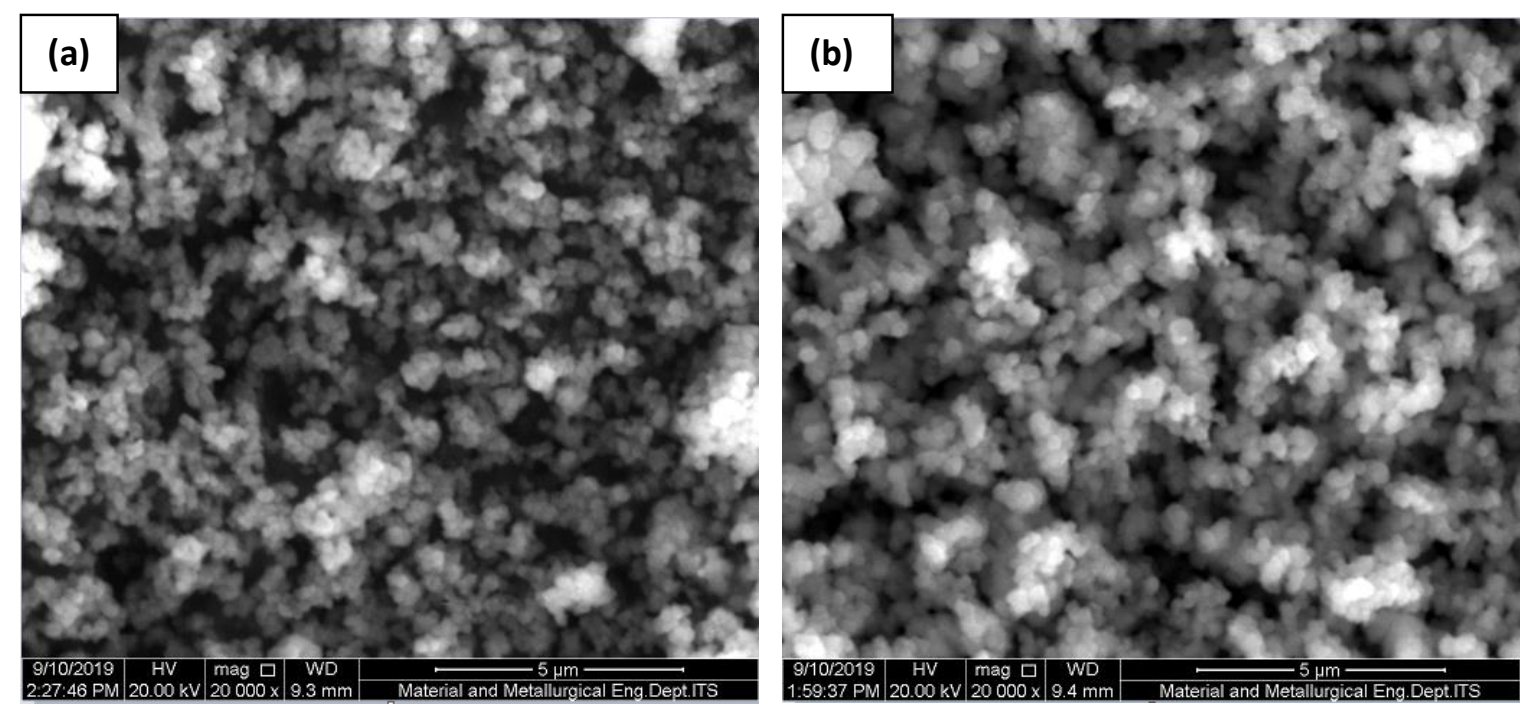

Gambar 3. Morfologi Permukaan: (a) UiO-66; (b) UiO-66 Loaded Ibuprofen 
Pemetaan hasil EDX UiO-66 sesudah loading ibuprofen ditunjukkan pada Gambar 4. Adapun komposisi unsur (wt\%) UiO-66 sebelum dan sesudah loading ibuprofen ditunjukkan pada Tabel 1. Hasil analisa EDX menunjukkan bahwa komposisi unsur karbon (C) UiO-66 mencapai 22,25 wt $\%$, unsur O mencapai 21,72 wt\% dan unsur $\mathrm{Zr}$ mencapai 54,36 wt $\%$. Setelah loading ibuprofen dalam UiO-66, komposisi unsur karbon (C) meningkat menjadi $45 \mathrm{wt} \%$, unsur oksigen (O) meningkat menjadi 25,52 wt\% dan unsur $\mathrm{Zr}$ menurun menjadi 27,22 wt\%. Hasil ini membuktikan bahwa ibuprofen telah berhasil masuk kedalam pori maupun permukaan UiO-66. Ibuprofen sebagian besar tersusun oleh unsur karbon (C) dan oksigen (O) sehingga pada UiO-66
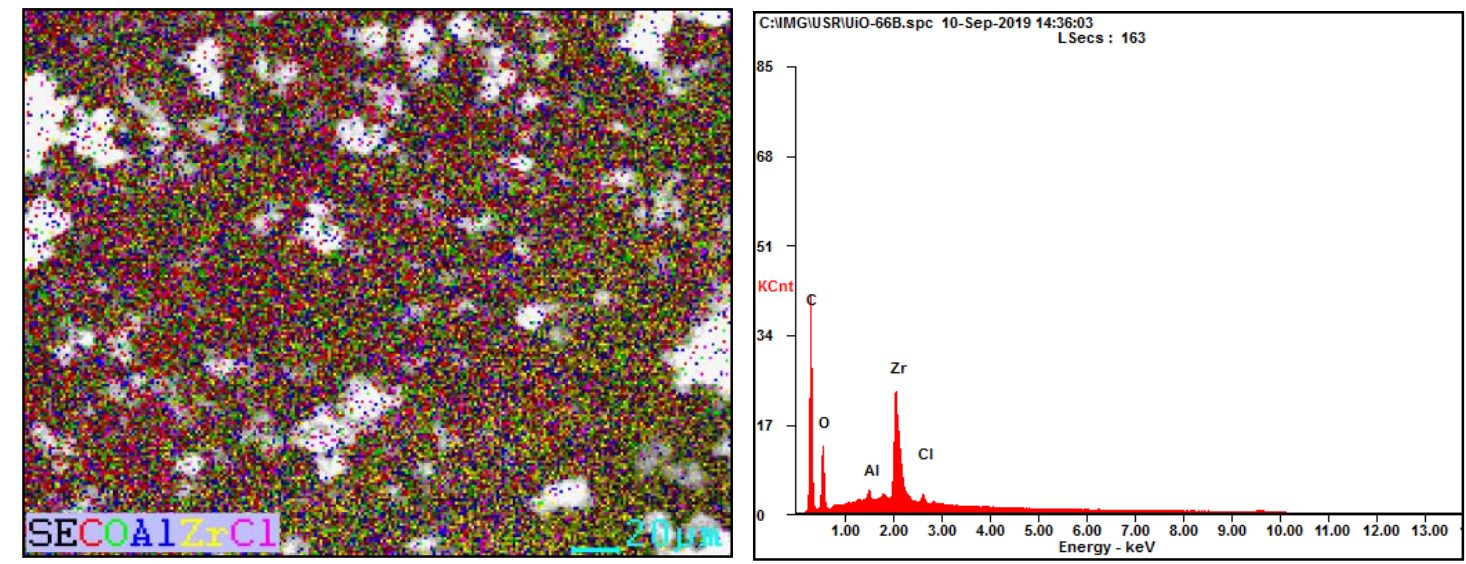

Gambar 4. Pemetaan hasil EDX UiO-66 Laoded Ibuprofen

\section{Uji Drug Loading Ibuprofen pada UiO66}

Gambar 5 menunjukkan pengaruh waktu pengadukan terhadap jumlah ibuprofen dalam UiO-66 (\% w/w). Pada penelitian ini waktu pengadukan yang dilakukan 0-72 jam dengan konsentrasi awal ibuprofen 1000 ppm. Gambar 5 menunjukkan bahwa semakin lama waktu pengadukan maka ibuprofen dalam UiO$66(\% \mathrm{w} / \mathrm{w})$ semakin meningkat. Hal ini sesuai dengan penelitian Sun dkk., (2012) yang menunjukkan bahwa semakin lama waktu pengadukan, maka jumlah 5-FU dalam MOF jenis ZIF-8 semakin meningkat. Drug loading optimum sesudah loading ibuprofen, komposisi unsur $\mathrm{C}$ dan $\mathrm{O}$ mengalami peningkatan, sedangkan $\mathrm{Zr}$ mengalami penurunan. Hasil ini sesuai dengan penelitian Ulfa, et al., (2018) yang menunjukkan bahwa komposisi unsur $\mathrm{C}$ akan mengalami peningkatan setelah adanya loading ibuprofen dalam SBA-15.

Tabel 1. Komposisi unsur (wt\%) UiO-66 sebelum dan sesudah loading ibuprofen

\begin{tabular}{lccc}
\hline \multirow{1}{*}{ Material } & \multicolumn{3}{c}{ wt (\%) } \\
\cline { 2 - 4 } & $\mathbf{C}$ & $\mathbf{O}$ & $\mathbf{Z r}$ \\
\hline UiO-66 & 22,25 & 21,72 & 54,36 \\
UiO-66 Loaded & 45,00 & 25,52 & 27,22 \\
Ibuprofen & & \\
\hline
\end{tabular}

ibuprofen dalam UiO-66 mencapai $82,79 \%$ pada waktu pengadukan 72 jam. Hasil ini lebih baik daripada penelitian Ulfa dkk., (2019) yang menunjukkan bahwa jumlah ibuprofen dalam SBA-15 maksimum $62,3 \mathrm{mg} / \mathrm{g}$. Disamping itu, hasil ini juga lebih baik dari hasil penelitian Sun, dkk., (2017) yang menunjukkan bahwa jumlah ibuprofen dalam MOF jenis HKUST maksimum $60 \%$. Hasil ini menunjukkan bahwa UiO66 potensial digunakan sebagai drug storage. 


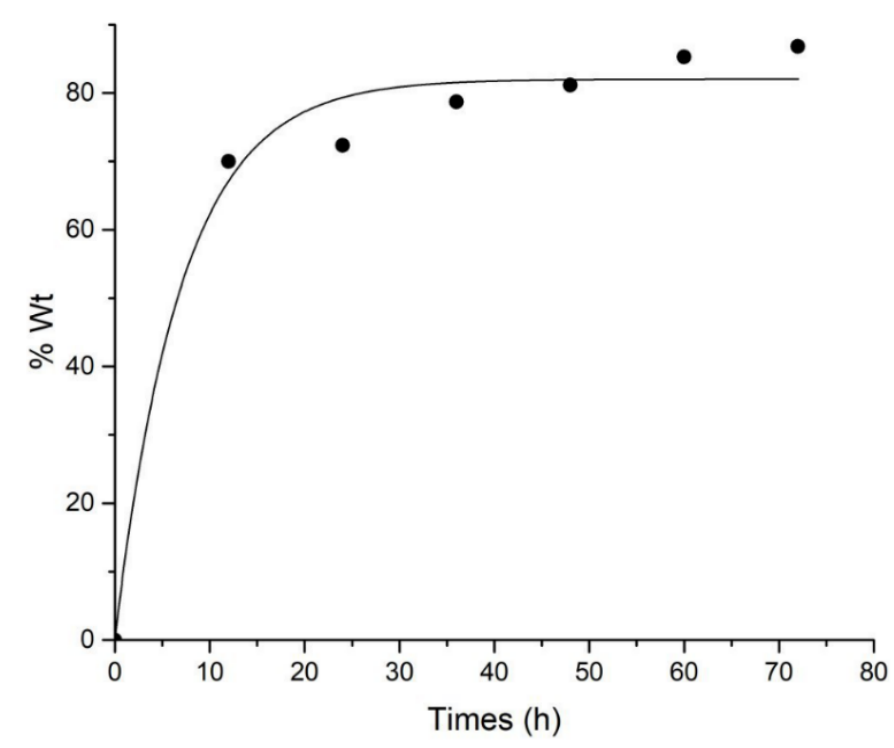

Gambar 5. Pengaruh Waktu Pengadukan Terhadap Jumlah Ibuprofen dalam UiO-66 (\% w/w)

\section{Kesimpulan}

Dari penelitian diperoleh hasil analisa gugus fungsi sampel dengan FourierTransform Infra Red (FTIR) dari UiO-66 menunjukkan bahwa puncak khas dari UiO-66 juga muncul pada 663, 748 dan $547 \mathrm{~cm}^{-1}$ yang menunjukkan adanya interaksi Zirkonium $(\mathrm{Zr})$ dengan ligan $\mathrm{H}_{2} \mathrm{BDC}$, setelah UiO-66 digunakan untuk loading Ibuprofen tidak mengubah posisi dari puncak-puncak UiO-66. Namun, terjadi penurunan intensitas dan hilangnya puncak disekitar $1300 \mathrm{~cm}^{-1}$ yang dikarenakan interaksi antara UiO-66 dengan ibuprofen. Pola difraktogram UiO66 sebelum dan sesudah loading ibuprofen yang menunjukkan bahwa UiO-66 yang terbentuk memiliki puncak karakteristik UiO-66 pada 7,3 . Mikrograf UiO-66 sebelum dan setelah loading ibuprofen

\section{Daftar Pustaka}

Abid, H. R., Tian, H., Ang, H. M., Tade, M. O., Buckley, C. E., \& Wang, S. 2012. Nanosize Zr-metal Organic Framework (UiO-66) for Hydrogen and Carbon dioxide Storage. Chemical Engineering Journal, 187, 415-420. memiliki morfologi kubus. Namun, setelah loading ibuprofen terdapat bagian seperti karang putih, ukuran yang terlihat lebih besar, serta pengurangan ruang kosong permukaan material UiO-66. Uji Drug Loading Ibuprofen pada UiO-66 menunjukkan loading optimum ibuprofen dalam UiO-66 mencapai $82,79 \%$ pada waktu pengadukan 72 jam.

\section{Ucapan Terima Kasih}

Penulis mengucapkan terima kasih kepada DRPM Kemenristekdikti yang telah mendanai penelitian ini melalui Hibah Penelitian Dosen Pemula Tahun 2019 serta Yayasan Bhakti Wiyata dan Institut Ilmu Kesehatan Bhakti Wiyata yang telah memberikan dukungan kepada penulis.

Cavka, J. H., Jakobsen, S., Olsbye, U., Guillou, N., Lamberti, C., Bordiga, S., \& Lillerud, K. P. 2008. A New Zirconium Inorganic Building Brick Forming Metal Organic Frameworks with Exceptional Stability. Journal of the American Chemical Society, 130(42), 13850-13851. 
Chavan, S., Vitillo, J. G., Gianolio, D., Zavorotynska, O., Civalleri, B., Jakobsen, S. \& Bordiga, S. 2012. $\mathrm{H}_{2}$ storage in Isostructural UiO-67 and UiO-66 MOFs. Physical Chemistry Chemical Physics, 14(5), 1614-1626.

DeCoste, J. B., Peterson, G. W., Schindler, B. J., Killops, K. L., Browe, M. A., \& Mahle, J. J. 2013. The Effect of Water Adsorption on the Structure of the Carboxylate Containing MetalOrganic Frameworks Cu-BTC, MgMOF-74, and UiO-66. Journal of Materials Chemistry A, 1(38), 1192211932.

Della Rocca, J., Liu, D., \& Lin, W. 2011. Nanoscale Metal-Organic Frameworks for Biomedical Imaging and Drug Delivery. Accounts of Chemical Research, 44(10), 957-968.

Haydar, M. A., Abid, H. R., Sunderland, B., \& Wang, S. 2017. Metal Organic Frameworks as A Drug Delivery System for Flurbiprofen. Drug Design, Development and Therapy, 11, 2685.

Jin, Z., \& Yang, H. 2017. Exploration of $\mathrm{Zr}$-Metal-Organic Framework as Efficient Photocatalyst for Hydrogen Production. Nanoscale Research Letters, 12(1), 539.

Kandiah, M., Nilsen, M. H., Usseglio, S., Jakobsen, S., Olsbye, U., Tilset, M. \& Lillerud, K. P. 2010. Synthesis and Stability of Tagged UiO-66 Zr-MOFs. Chemistry of Materials, 22(24), 66326640.

Li, H., Lv, N., Li, X., Liu, B., Feng, J., Ren, X., \& Zhang, J. 2017. Composite CDMOF Nanocrystals-Containing Microspheres for Sustained Drug Delivery. Nanoscale, 9(22), 74547463.

Li, Q. L., Wang, J. P., Liu, W. C., Zhuang, X. Y., Liu, J. Q., Fan, G. L., \& Man, J. H. 2015. A New $(4,8)$-Connected Topological MOF as Potential Drug Delivery. Inorganic Chemistry Communications, 55, 8-10.
Mulyati, T. A., Ediati, R., \& Rosyidah, A. 2015. Influence of Solvothermal Temperatures and Times on Crystallinity and Morphology of MOF-5. Indonesian Journal of Chemistry, 15(2), 101-107.

Nurahmanto, D., Mahrifah, I. R., Azis, R. F. N. I., \& Rosyidi, V. A. 2017. Formulasi Sediaan Gel Dispersi Padat Ibuprofen: Studi Gelling Agent dan Senyawa Peningkat Penetrasi. Jurnal Ilmiah Manuntung, 3(1), 96-105.

Ragon, F., Horcajada, P., Chevreau, H., Hwang, Y. K., Lee, U. H., Miller, S. R., \& Serre, C. 2014. In situ EnergyDispersive X-Ray Diffraction for The Synthesis Optimization and Scale-Up of the Porous Zirconium Terephthalate UiO-66. Inorganic Chemistry, 53(5), 2491-2500.

Rahmawati, I. D., Ediati, R., \& Prasetyoko, D. 2014. Synthesis of UiO-66 Using Solvothermal Method at High Temperature. IPTEK Journal of Proceedings Series, 1(1).

Rojas, S., Baati, T., Njim, L., Manchego, L., Neffati, F., Abdeljelil, N., \& Horcajada, P. 2018. Metal-Organic Frameworks as Efficient Oral Detoxifying Agents. Journal of the American Chemical Society, 140(30), 9581-9586.

Rojas, S., Colinet, I., Cunha, D., Hidalgo, T., Salles, F., Serre, C., ... \& Horcajada, P. 2018. Toward Understanding Drug Incorporation and Delivery from Biocompatible Metal-Organic Frameworks in View of Cutaneous Administration. ACS omega, 3(3), 2994-3003.

Sa'diah, K. 2017. Sintesis dan Karakterisasi Selulosa Poli-Etilen Glikol (PEG) Sebagai Sistem Penghantar Obat (SPO). Fakultas Matematika dan Ilmu Pengetahuan Alam. Universitas Lampung.

Sun, C. Y., Qin, C., Wang, X. L., Yang, G. S., Shao, K. Z., Lan, Y. Q. \& Wang, E. B. 2012. Zeolitic Imidazolate 
Framework-8 as Efficient $\mathrm{pH}-$ Sensitive Drug Delivery Vehicle. Dalton Transactions, 41(23), 69066909.

Sun, K., Li, L., Yu, X., Liu, L., Meng, Q., Wang, F., \& Zhang, R. 2017. Functionalization of Mixed Ligand Metal-Organic Frameworks as the Transport Vehicles for Drugs. Journal of Colloid and Interface Science, 486, 128-135.

Sun, W., Li, H., li, H., Li, S., Cao, X. 2019. Adsorption Mechanisms of Ibuprofen and Naproxen to UiO-66 and UiO66 $\mathrm{NH}_{2}$ : Batch Experiment and DFT Calculation. Chemical Enginering Journal, 360, 645-653

Tai, S., Zhang, W., Zhang, J., Luo, G., Jia, Y., Deng, M., \& Ling, Y. 2016. Facile Preparation of UiO-66 Nanoparticles with Tunable Sizes in A Continuous Flow Microreactor and Its Application in Drug Delivery. Microporous and Mesoporous Materials, 220, 148-154.

Ulfa, M., \& Prasetyoko, D. 2018. Infrared Spectroscopic and Scanning Electron Microscopy Study of Ibuprofen Loading onto the Molecular Sieve Mesoporous Silica SBA-15 Material. Oriental Journal of Chemistry, 34(5), 2631.

Ulfa, M., \& Prasetyoko, D. 2019. Drug Loading-Release Behaviour of Mesoporous Materials SBA-15 and CMK-3 Using Ibuprofen Molecule as Drug Model. Journal of Physics: Conference Series (Vol. 1153, No. 1, p. 012065). IOP Publishing. 